\title{
Classification of Coryneform Bacteria Associated with Human Urinary Tract Infection (Group D2) as Corynebacterium urealyticum sp. nov.
}

\author{
DAVID PITCHER, ${ }^{1 *}$ ALICIA SOTO,${ }^{2}$ FRANCISCO SORIANO ${ }^{2}$ AND PEDRO VALERO-GUILLÉN ${ }^{3}$ \\ National Collection of Type Cultures, Central Public Health Laboratory, 61 Colindale Avenue, London NW9 5HT, United \\ Kingdom, ${ }^{1}$ and Department of Clinical Microbiology, Fundación Jiménez Díaz, 28040 Madrid, ${ }^{2}$ and Department of \\ Genetics and Microbiology, University of Murcia, 30100 Murcia, ${ }^{3}$ Spain
}

\begin{abstract}
Urealytic strains of coryneform bacteria that are designated Corynebacterium group D2 and are isolated from human urine are a cause of urinary tract infections. Cell wall and lipid analyses confirmed that these organisms are members of the genus Corynebacterium but can be separated from other species in the genus on the basis of DNA base composition and DNA-DNA hybridization values. Biochemically, strains in this taxon can be distinguished from other Corynebacterium spp. by their failure to produce acid from carbohydrates, by their failure to reduce nitrates, and by their ability to hydrolyze urea. We regard these bacteria as a new species of the genus Corynebacterium and propose the name Corynebacterium urealyticum. The type strain is strain NCTC 12011 (= ATCC 43042).
\end{abstract}

The identification system for medically important coryneform bacteria devised by the Centers for Disease Control, Atlanta, Ga., designates one group of urealytic, nonfermentative bacteria as Corynebacterium group D2 and suggests that these organisms may be nitrate-negative variants of Corynebacterium pseudodiphtheriticum (9). This group has tentatively been referred to as Corynebacterium urealyticum (23), but this name has not been validly published previously. Strains identified as $C$. urealyticum have been associated with cases of encrusted cystitis and other urinary tract infections in hospital patients (20), where they have been highly resistant to antibiotics (22). The natural habitat of these strains is human skin (24), but they readily colonize urinary tracts (22); strains have also been isolated from blood $(14,17)$ and wounds $(28)$. C. urealyticum is relatively inactive in conventional tests apart from its ability to hydrolyze urea rapidly. Colonially and microscopically, this species resembles Corynebacterium jeikeium, with which it shares a common habitat and resistance to antibiotics (4). However, the latter species is consistently nonurealytic and acidifies glucose and maltose. Evidence from lipid analysis $(7,21)$, from pyrolysis-mass spectrometry (8), and from rRNA gene restriction fragment polymorphism studies (26) indicates that there are clear differences between the two species. Chemotaxonomic evidence that group D2 is related to the genus Corynebacterium has been provided by Herrera-Alcarez et al. (7), who determined that the cell wall type is chemotype IV, with mycolic acids having chain lengths of 26 to 36 carbon atoms, and that the isoprenoid quinone MK- $9\left(\mathrm{H}_{2}\right)$ is present.

In this study, we estimated the DNA base compositions of Corynebacterium strains and levels of DNA-DNA relatedness between strains of $C$. urealyticum and other Corynebacterium species; we concluded that this taxon merits status as a new species in the genus Corynebacterium.

\footnotetext{
* Corresponding author
}

\section{MATERIALS AND METHODS}

Bacterial strains and culture. The strains used in this study are listed in Table 1. Strains identified as $C$. urealyticum were isolated in Madrid, Spain, from the urine (strains A516/89, A524/90, A532/90, A548/90, and NCTC $12011^{\mathrm{T}}$ [T = type strain]) and skin (strain A545/90) of hospital patients. Cultures were maintained in the freeze-dried state, plated onto $5 \%$ horse blood nutrient agar, and incubated at $37^{\circ} \mathrm{C}$ for $48 \mathrm{~h}$. To prepare DNA, strains were subcultured in $100 \mathrm{ml}$ of brain heart infusion broth (Oxoid, London, United Kingdom) supplemented with $0.4 \%$ yeast extract and $0.2 \%$ (vol vol) Tween 80 and incubated aerobically with shaking at $37^{\circ} \mathrm{C}$ for $48 \mathrm{~h}$.

Preparation of DNA. Cells $(0.5$ to $1.0 \mathrm{~g})$ were pelleted by centrifugation, washed once with TE buffer $(10 \mathrm{mM}$ Tris$\mathrm{HCl}, 1 \mathrm{mM}$ EDTA; $\mathrm{pH} 8.0$ ), and incubated in $0.5 \mathrm{ml}$ of a lysozyme solution $\left(50 \mathrm{mg} \cdot \mathrm{ml}^{-1}\right.$ in TE buffer) at $37^{\circ} \mathrm{C}$ for 1 h. DNA was extracted as described previously (19), except that five times the stated volumes of reagents were used. The DNA was further purified by incubating it in RNase-SET (20 $\mu \mathrm{g}$ of RNase A per $\mathrm{ml}$ in $150 \mathrm{mM} \mathrm{NaCl}-15 \mathrm{mM}$ EDTA-60 $\mathrm{mM}$ Tris- $\mathrm{HCl}\left[\mathrm{pH} \mathrm{8.3])} \mathrm{at} 37^{\circ} \mathrm{C}\right.$ for $1 \mathrm{~h}$. Proteinase $\mathrm{K}$ was added to a final concentration of $50 \mu \mathrm{g} \cdot \mathrm{ml}^{-1}$, and incubation was continued for $1 \mathrm{~h}$. The solution was mixed with an equal volume of TE buffer-saturated phenol-chloroform (1:1, $\mathrm{vol} / \mathrm{vol}$ ) and centrifuged at $20,000 \times \mathrm{g}$ for $30 \mathrm{~min}$; this was followed by extractions with equal volumes of chloroform until all of the visible precipitate was removed.

Purified DNA was precipitated with 1 volume of 2-propanol, washed three times with $70 \%$ ethanol, and dried under a vacuum for $10 \mathrm{~min}$.

DNA base composition. Purified DNA samples were dissolved in $0.1 \times \mathrm{SSC}(1 \times \mathrm{SSC}$ is $0.15 \mathrm{M} \mathrm{NaCl}$ plus $0.015 \mathrm{M}$ trisodium citrate, $\mathrm{pH} 7.0$ ), and the $A_{280}, A_{260}$, and $A_{230}$ were determined to estimate concentration and purity. The concentration was adjusted to approximately $50 \mu \mathrm{g} \cdot \mathrm{ml}^{-1}$ with $0.1 \times \mathrm{SSC}$, and the guanine-plus-cytosine $(\mathrm{G}+\mathrm{C})$ content was determined by using the thermal denaturation method (16). A DNA sample from Escherichia coli NCTC 9001 was used as a standard $(52 \mathrm{~mol} \% \mathrm{G}+\mathrm{C})$.

DNA-DNA hybridizations. Nitrocellulose-bound DNA was 
TABLE 1. DNA base compositions and levels of DNA relatedness between strains of $C$. urealyticum and other Corynebacterium species

\begin{tabular}{|c|c|c|c|c|c|c|}
\hline \multicolumn{2}{|c|}{ Source of unlabeled DNA } & \multirow{2}{*}{$\begin{array}{c}\mathrm{G}+\mathrm{C} \\
\text { content } \\
(\mathrm{mol} \%)^{a}\end{array}$} & \multicolumn{4}{|c|}{ Relative $\%$ of binding with ${ }^{3} \mathrm{H}$-labeled DNA from: } \\
\hline $\begin{array}{l}\text { Species or } \\
\text { subspecies }\end{array}$ & Strain & & $\begin{array}{l}\text { Strain NCTC } \\
12011^{\mathbf{T}}\end{array}$ & $\begin{array}{c}\text { Strain } \\
\text { A516/89 }\end{array}$ & $\begin{array}{c}\text { Strain } \\
\text { A545/90 }\end{array}$ & $\begin{array}{c}\text { Strain } \\
\text { A548/90 }\end{array}$ \\
\hline \multirow[t]{6}{*}{ C. urealyticum } & $\operatorname{NCTC} 12011^{\mathrm{T}}\left(=\operatorname{ATCC} 43042^{\mathrm{T}}\right)$ & 62 & 100 & & & \\
\hline & A516/89 & 62 & 84 & 100 & & \\
\hline & A545/90 & 62 & 88 & 76 & 100 & \\
\hline & A548/90 & 62 & 81 & 78 & 82 & 100 \\
\hline & A532/90 & 62 & 88 & 70 & 100 & 93 \\
\hline & A524/90 & 61 & 71 & 84 & 96 & 89 \\
\hline C. bovis & $\operatorname{NCTC} 3224^{\mathrm{T}}\left(=\operatorname{ATCC} 7715^{\mathrm{T}}\right)$ & 70 & 4 & 8 & 3 & 6 \\
\hline C. cystiditis & NCTC $11863^{\mathrm{T}}\left(=\right.$ ATCC $\left.29593^{\mathrm{T}}\right)$ & 70 & 3 & 1 & 1 & 4 \\
\hline C. diphtheriae & NCTC $11397^{\mathrm{T}}\left(=\right.$ ATCC $\left.27010^{\mathrm{T}}\right)$ & 54 & 2 & 2 & 1 & 3 \\
\hline C. flavescens & NCIMB $8707^{\mathrm{T}}\left(=\right.$ ATCC $\left.10340^{\mathrm{T}}\right)$ & 59 & 2 & 2 & 1 & 5 \\
\hline C. jeikeium & NCTC $11913^{\mathrm{T}}\left(=\right.$ ATCC $\left.43734^{\mathrm{T}}\right)$ & 60 & 22 & 8 & 8 & 9 \\
\hline C. matruchotii & NCTC $10254^{\mathrm{T}}\left(=\operatorname{ATCC} 14266^{\mathrm{T}}\right)$ & 56 & 3 & 2 & 1 & 5 \\
\hline C. minutissimum & NCTC $10288^{\mathrm{T}}\left(=\right.$ ATCC $\left.23348^{\mathrm{T}}\right)$ & 59 & 3 & 3 & 2 & 6 \\
\hline C. mycetoides & NCTC $9864^{\mathrm{T}}$ & 65 & 5 & 4 & 4 & 5 \\
\hline C. pilosum & NCTC $11862^{\mathrm{T}}\left(=\operatorname{ATCC} 29592^{\mathrm{T}}\right)$ & 61 & 19 & 2 & 4 & 10 \\
\hline C. pseudodiphtheriticum & NCTC $11136^{\mathrm{T}}\left(=\right.$ ATCC $\left.10700^{\mathrm{T}}\right)$ & 55 & 2 & 3 & 1 & 5 \\
\hline C. pseudotuberculosis & NCTC $3450^{\mathrm{T}}\left(=\operatorname{ATCC} 19410^{\mathrm{T}}\right)$ & 52 & 1 & 1 & 1 & 2 \\
\hline C. renale & NCTC $7448^{\mathrm{T}}\left(=\right.$ ATCC $\left.19412^{\mathrm{T}}\right)$ & 58 & 19 & 3 & 4 & 8 \\
\hline C. striatum & $\operatorname{NCTC} 764^{\mathrm{T}}\left(=\operatorname{ATCC} 6940^{\mathrm{T}}\right)$ & 58 & 6 & 3 & 1 & 4 \\
\hline C. variabilis & NCIMB $9455^{\mathrm{T}}\left(=\right.$ ATCC $\left.15753^{\mathrm{T}}\right)$ & 65 & 2 & 3 & 1 & 3 \\
\hline C.xerosis & $\operatorname{NCTC} 11861^{\mathrm{T}}\left(=\operatorname{ATCC} 373^{\mathrm{T}}\right)$ & 68 & 6 & 4 & 2 & 4 \\
\hline $\begin{array}{l}\text { Alcaligenes xylosoxidans } \\
\text { subsp. denitrificans }\end{array}$ & NCTC 10807 (= ATCC 27061) & 69 & 1 & 1 & 0 & 4 \\
\hline
\end{tabular}

${ }^{a}$ Data from this study and reference 10.

prepared, and the direct membrane hybridization procedure was performed as described by Johnson (11). Radiolabeled DNA was prepared by random primer extension, using a kit (Boehringer Mannheim Ltd., Lewes, United Kingdom) that incorporated deoxy $\left[1^{\prime}, 2^{\prime}, 5-{ }^{3} \mathrm{H}\right] \mathrm{CTP}$ (Amersham International PLC, Aylesbury, United Kingdom). According to the manufacturer's instructions, $25 \mathrm{ng}$ of DNA was labeled for every 10 hybridization reactions. Labeled DNA was purified on a Sephadex G-50 spun column (15) and sonicated for 2 min, and volumes containing $20,000 \mathrm{cpm}$ were added to each membrane filter (diameter, $6 \mathrm{~mm}$ ). Hybridization was carried out in $5 \times \mathrm{SSC}-50 \%$ formamide at the optimum reassociation temperature $\left(45^{\circ} \mathrm{C}\right)$ in a shaking water bath for $20 \mathrm{~h}$. Filters were washed three times in $2 \times \mathrm{SSC}$ at the stringent temperature $\left(84^{\circ} \mathrm{C}\right)$ with agitation. The filters were placed in scintillation vials containing $2 \mathrm{ml}$ of Ready Protein + scintillation cocktail (Beckman Instruments Ltd., High Wycombe, United Kingdom) and dissolved overnight, and radioactivity was measured with a Tri-Carb 4000 liquid scintillation counter (United Technologies, Packard, Pangbourne, United Kingdom). DNA from Alcaligenes xylosoxidans subsp. denitrificans NCTC 10807 was used as a nonhomologous control $(\mathrm{G}+\mathrm{C}$ content, $69 \mathrm{~mol} \%)(13)$.

\section{RESULTS AND DISCUSSION}

The DNA base compositions of the six strains of $C$. urealyticum which we used ranged from 61 to $62 \mathrm{~mol} \%$ $\mathrm{G}+\mathrm{C}$. A comparison with the type strains of 15 Corynebacterium species (Table 1) showed that Corynebacterium favescens NCIMB 8707, C. jeikeium NCTC 11913, Corynebacterium minutissimum NCTC 10288, Corynebacterium pilosum NCTC 11862, Corynebacterium renale NCTC 7448, Corynebacterium striatum NCTC 764, and Corynebacterium variabilis NCIMB 9455 all had DNA base composition values within $5 \%$ of this range, which is consistent with the range for strains within a species $(3,12)$. However, the results of DNA pairing experiments (Table 1) showed that none of the type strains of the Corynebacterium species tested, including the type species, Corynebacterium diphtheriae, exhibited close DNA relatedness with $C$. urealyticum. The levels of interstrain homology among the six strains of this species $(>60 \%)$ are consistent with the criterion for a homogeneous species (12), and the particularly low values obtained in the comparisons of $C$. urealyticum DNA with DNAs of other species $(<23 \%)$ suggest that the proposed species has no close relatives among the other species which we examined. In addition, the low DNA base composition of C. urealyticum, together with the presence of mycolic acids $\left(\mathrm{C}_{26}\right.$ to $\left.\mathrm{C}_{36}\right)$ that yield low-molecular-weight pyrolysis products ( $\mathrm{C}_{8}$ to $\mathrm{C}_{12}$ methyl esters), excludes this organism from the genera Rhodococcus and Gordona.

Our data confirmed previous findings which indicated that the taxon designated Corynebacterium group D2 by the Centers for Disease Control (9) and referred to as $C$. urealyticum (23) could represent a single species on the basis of evidence from phenotypic tests (including API profiles) (5, 27), pyrolysis-mass spectrometry (8), fatty acid, isoprenoid quinone, and phospholipid analyses $(7,21)$, and rRNA gene profiling (26). The presence of a meso-diaminopimelic acidbased peptidoglycan, the presence of a cell wall arabinogalactan, and the presence of short-chain mycolic acids are characteristics which $C$. urealyticum shares with the type species of the genus Corynebacterium, $C$. diphtheriae, indicating that the new species should be placed in this genus (2).

C. urealyticum contains tuberculostearic acid (10-methyloctadecanoic acid) (21), a lipid that is associated with the genera Rhodococcus, Gordona, Nocardia, Mycobacterium, and Tsukamurella ("aurantiaca" taxon) (6). However, the presence of tuberculostearic acid has been detected in other 
TABLE 2. Some characteristics that are useful for differentiating $C$. urealyticum from other commensal Corynebacterium species found on human skin

\begin{tabular}{|c|c|c|c|c|c|c|}
\hline \multirow{2}{*}{ Species } & \multicolumn{3}{|c|}{ Aerobic acid production from ${ }^{a}$ : } & \multirow{2}{*}{$\begin{array}{l}\text { Nitrate }^{\alpha} \\
\text { reduction }\end{array}$} & \multirow{2}{*}{$\begin{array}{l}\text { Urease }^{a} \\
\text { activity }\end{array}$} & \multirow{2}{*}{$\begin{array}{l}\text { Isoprenoid } \\
\text { quinone }(\mathbf{s})^{b}\end{array}$} \\
\hline & Glucose & Maltose & Sucrose & & & \\
\hline C. urealyticum & $-{ }^{c}$ & - & - & - & + & MK-9 $\left(\mathrm{H}_{2}\right)$ \\
\hline C. jeikeium & + & $\mathrm{v}$ & - & - & - & $\mathrm{ND}^{d}$ \\
\hline C. bovis & + & - & - & - & - & $\mathrm{MK}-9\left(\mathrm{H}_{2}\right)$ \\
\hline C. minutissimum & + & + & + & - & - & $\operatorname{MK}-8\left(\mathrm{H}_{2}\right)+\operatorname{MK}-9\left(\mathrm{H}_{2}\right)$ \\
\hline C. pseudodiphtheriticum & - & - & - & + & + & $\mathrm{MK}-8\left(\mathrm{H}_{2}\right)$ \\
\hline C. striatum & + & - & + & + & - & $\mathrm{MK}-8\left(\mathrm{H}_{2}\right)$ \\
\hline C. xerosis & + & $\mathrm{v}$ & $\mathbf{v}$ & + & - & $\mathrm{MK}-8\left(\mathrm{H}_{2}\right)$ \\
\hline
\end{tabular}

${ }^{a}$ Data from reference 9.

${ }^{b}$ Data from reference 3 .

$c+$, positive; - , negative; $v$, variable.

${ }^{d} \mathrm{ND}$, not determined.

Corynebacterium species, notably Corynebacterium bovis (6) and C. variabilis (1). Although the presence of tuberculostearic acid in $C$. minutissimum has been reported by Collins (1), this compound was not detected by HerreraAlcarez et al. (7). The latter authors also found that this fatty acid is present in Corynebacterium cystitidis and C.pseudodiphtheriticum in small amounts. Another lipid which has been suggested as a taxonomic marker is phosphatidylethanolamine. This compound was found by Minnikin et al. (18) to be absent in the genus Corynebacterium but present in the genera Rhodococcus, Gordona, Nocardia, and Mycobacterium, although sometimes it was present in trace amounts. However, Herrera-Alcarez et al. (7) have reported the presence of phosphatidylethanolamine in C. bovis, C. cystitidis, Corynebacterium ammoniagenes, and $C$. pseudodiphtheriticum. These findings suggest that the presence of tuberculostearic acid and the presence of phosphatidylethanolamine are unreliable as taxonomic markers and may depend on culture conditions.

The most significant phenotypic characteristic which $C$. urealyticum shares with some other Corynebacterium species is the possession of a potent urease activity. This property is considered to be important in the ability of the organism to infect human urinary tracts and to induce the formation of struvite (ammonium magnesium phosphate) stones $(22,23)$, a property that so far has not been reported for other Corynebacterium species. Other urealytic species ( $C$. renale, $C$. cystitidis, and $C$. pilosum) which may be urinary tract pathogens in animals differ from $C$. urealyticum in their ability to produce acid from sugars. C. pseudodiphtheriticum, a urealytic, nonfermentative commensal of human skin, differs from $C$. urealyticum in being able to reduce nitrate. Most $C$. urealyticum isolates are resistant to antibiotics, but a few $(<5 \%)$ harbor plasmids $(25)$; strains of this species appear to colonize the skin of hospital patients and are similar in this respect to isolates of $C$. jeikeium, which they resemble morphologically and colonially. In addition, the growth of both species is considerably enhanced by including Tween 80 in the media, and these properties may make the two taxa difficult to distinguish on initial isolation. However, C. jeikeium is consistently nonurealytic and produces acid from glucose, and on this basis an identification can be made. Table 2 lists some of the characteristics that distinguish $C$. urealyticum from other commensal Corynebacterium species that are commonly encountered on human skin.

We believe that there is sufficient evidence to justify the creation of a new species in the genus Corynebacterium to accommodate strains that were previously designated group D2 strains. The name Corynebacterium urealyticum is proposed for this taxon.

Description of Corynebacterium urealyticum sp. nov. Corynebacterium urealyticum (u.re.a.ly'ti.cum. M.L. fem. $n$. urea, urea; Gr. adj. lyticus, dissolving; M.L. neut. adj. urealyticum, urea dissolving). Gram-positive cells that are not acid fast and are nonsporing and after prolonged culture may be coccoid. Cells (diameter, 0.5 to $1 \mu \mathrm{m}$ ) are arranged in palisades and $\mathrm{V}$ shapes with no tendency to branch. The bacteria grow on blood agar as pinpoint colonies after $48 \mathrm{~h}$ of incubation at 25,37 , and $42^{\circ} \mathrm{C}$. Colonies are whitish, opaque, smooth, convex, and nonhemolytic. Does not grow on blood agar incubated anaerobically for $48 \mathrm{~h}$ or on MacConkey agar. Nonmotile, catalase positive, and oxidase negative. Acid is not produced from glucose, sucrose, maltose, mannitol, xylose, ribose, L-arabinose, sorbitol, lactose, trehalose, inulin, raffinose, starch, and glycogen. Does not hydrolyze gelatin or esculin. Nitrate is not reduced. Does not degrade DNA. Possesses strong urease activity. Hydrolyzes Tween 80. Growth is stimulated by Tween 80 . A few strains hydrolyze hippurate or give a positive Voges-Proskauer reaction. The peptidoglycan contains meso-diaminopimelic acid. The cell wall contains arabinose and galactose. The saturated and nonsaturated fatty acids $\left(\mathrm{C}_{14}\right.$ to $\left.\mathrm{C}_{18}\right)$ consist of tetradecanoic, hexadecanoic, hexadecenoic, octadecanoic, octadecenoic, octadecadienoic, and 10-methyloctadecanoic (tuberculostearic) acids. Mycolic acids $\mathrm{C}_{26}$ to $\mathrm{C}_{36}$ are present. The major menaquinone is $\mathrm{MK}-9\left(\mathrm{H}_{2}\right)$. Contains diphosphatidylglycerol, phosphatidylglycerol, phosphatidylethanolamine, phosphatidylinositol, and phosphatidylinositol mannosides.

The DNA base composition is 61 to $62 \mathrm{~mol} \% \mathrm{G}+\mathrm{C}$.

Source: human urine, skin, and blood.

The type strain is strain NCTC 12011 (= ATCC 43042), which has a $\mathrm{G}+\mathrm{C}$ content of $62 \mathrm{~mol} \%$ (as determined by the thermal denaturation method).

\section{ACKNOWLEDGMENTS}

A.S. was supported by funds from the Conchita Rábago de Jiménez Díaz Foundation and the British Council.

\section{REFERENCES}

1. Collins, M. D. 1987. Transfer of Arthrobacter variabilis (Müller) to the genus Corynebacterium, as Corynebacterium variabilis comb. nov. Int. J. Syst. Bacteriol. 37:287-288.

2. Collins, M. D., and C. S. Cummins. 1986. Genus Corynebacterium, Lehmann and Neumann 1896, p. 1266-1276. In P. H. A 
Sneath, N. S. Mair, M. E. Sharpe, and J. G. Holt (ed.), Bergey's manual of systematic bacteriology, vol. 2. The Williams \& Wilkins Co., Baltimore.

3. Collins, M. D., M. Goodfellow, and D. E. Minnikin. 1979. Isoprenoid quinones in the classification of coryneform and related bacteria. J. Gen. Microbiol. 110:127-136.

4. Fernández-Roblas, R., S. Prieto, M. Santamaría, C. Ponte, and F. Soriano. 1987. Activity of nine antimicrobial agents against Corynebacterium group D2 strains isolated from clinical specimens and skin. Antimicrob. Agents Chemother. 31:821-822.

5. Freney, J., M. T. Duperron, C. Courtier, W. Hansen, F. Allard, J. M. Boeufgras, D. Monget, and J. Fleurette. 1991. Evaluation of API Coryne in comparison with conventional methods for identifying coryneform bacteria. J. Clin. Microbiol. 29:38-41.

6. Goodfellow, M. 1986. Genus Rhodococcus, Zopf 1891, p. 1472 1481. In P. H. A. Sneath, N. S. Mair, M. E. Sharpe, and J. G. Holt (ed.), Bergey's manual of systematic bacteriology, vol. 2. The Williams \& Wilkins Co., Baltimore.

7. Herrera-Alcarez, E. A., P. L. Valero-Guillén, F. Martin-Luengo and F. Soriano. 1990. Taxonomic implications of the chemical analysis of the D2 group of corynebacteria. FEMS Microbiol. Lett. 72:341-344.

8. Hindmarch, J. M., J. T. Magee, M. A. Hadfield, and B. I. Duerdin. 1990. A pyrolysis-mass spectrometry study of Corynebacterium spp. J. Med. Microbiol. 31:137-149.

9. Hollis, D. G., and R. E. Weaver. 1984. Gram-positive organisms: a guide to identification. Special Bacteriology Section, Centers for Disease Control, Atlanta, Ga.

10. Jackman, P. J. H., D. G. Pitcher, S. Pelcynska, and P. Borman. 1987. Classification of corynebacteria associated with endocarditis (group JK) as Corynebacterium jeikeium sp. nov. Syst. Appl. Microbiol. 9:83-90.

11. Johnson, J. L. 1981. Genetic characterization, p. 450-472. In P. Gerhardt, R. G. E. Murray, R. N. Costilow, E. W. Nester, W. A. Wood, N. R. Krieg, and G. B. Phillips (ed.), Manual of methods for general bacteriology. American Society for Microbiology, Washington, D.C.

12. Johnson, J. L. 1984. Nucleic acids in bacterial classification, p. 8-11. In N. R. Krieg and J. G. Holt (ed.), Bergey's manual of systematic bacteriology, vol. 1. The Williams \& Wilkins Co., Baltimore.

13. Kersters, K., and J. De Ley. 1984. Genus Alcaligenes, Castellani and Chalmers 1919, p. 367-370. In N. R. Krieg and J. G. Holt (ed.), Bergey's manual of systematic bacteriology, vol. 1. The Williams \& Wilkins Co., Baltimore.

14. Langs, J. C., D. de Briel, C. Sauvage, J. F. Blickle, and H. Akel. 1988. Endocardité a Corynebacterium du group D2, a point de depart urinaire. Med. Mal. Inf. 5:293-295.
15. Maniatis, T., E. F. Fritsch, and J. Sambrook. 1982. Molecular cloning: a laboratory manual. Cold Spring Harbor Laboratory, Cold Spring Harbor, N.Y.

16. Marmur, J., and P. Doty. 1962. Determination of the base composition of deoxyribonucleic acid from its thermal denaturation temperature. J. Mol. Biol. 5:109-118.

17. Marshall, R. J., K. R. Routh, and A. P. MacGowan. 1987 Corynebacterium CDC group D2 bacteraemia. J. Clin. Pathol. 40:813-815.

18. Minnikin, D. E., P. V. Patel, L. Alshamaony, and M. Goodfellow. 1977. Polar lipid composition in the classification of Nocardia and related bacteria. Int. J. Syst. Bacteriol. 27:104-117.

19. Pitcher, D. G., N. A. Saunders, and R. J. Owen. 1989. Rapid extraction of bacterial genomic DNA with guanidium thiocyanate. Lett. Appl. Microbiol. 8:151-156.

20. Soriano, F., J. M. Aguado, C. Ponte, R. Fernández-Roblas, and J. L. Rodríguez-Tudela. 1990. Urinary tract infection by Corynebacterium group D2: report of 82 cases and review. Rev. Infect. Dis. 12:1019-1034.

21. Soriano, F., F. Martín-Luengo, P. L. Valero, C. Ponte, M. Santamaría, and R. Fernández-Roblas. 1988. Caracterización e identificación de Corynebacterium grupo D2 aislados de muestras clínicas. Enf. Infec. Microbiol. Clin. 6:235-238.

22. Soriano, F., C. Ponte, M. Santamaría, J. M. Aguado, I. Wilhelmi, R. Vela, and L. Cifuentes. 1985. Corynebacterium group D2 as a cause of alkaline-encrusted cystitis. Report of four cases and characterization of the organisms. J. Clin. Microbiol. 21:788-792.

23. Soriano, F., C. Ponte, M. Santamaría, C. Castilla, and R. Fernández-Roblas. 1986. In vitro and in vivo study of stone formation by Corynebacterium group D2 (Corynebacterium urealyticum). J. Clin. Microbiol. 23:691-694.

24. Soriano, F., J. L. Rodriguez-Tudela, R. Fernández-Roblas, J. M. Aguado, and M. Santamaría. 1988. Skin colonization by Corynebacterium groups D2 and JK in hospitalized patients. J. Clin. Microbiol. 26:1878-1880.

25. Soto, A. Unpublished data.

26. Soto, A., D. G. Pitcher, and F. Soriano. 1991. A numerical analysis of ribosomal RNA gene patterns for typing clinica isolates of Corynebacterium group D2. Epidemiol. Infect. 107: 263-272.

27. Tillotson, G., M. Arora, M. Robbins, and J. Holton. 1988 Identification of Corynebacterium CDC group D2 with the API 20 Strep system. Eur. J. Clin. Microbiol. Infect. Dis. 7:675-678.

28. Van Bosterhaut, B., G. Claeys, J. Gigi, and G. Wauters. 1987. Isolation of Corynebacterium group D2 from clinical specimens Eur. J. Clin. Microbiol. 6:418-419. 